\title{
Integrasi Nilai Islami dengan Pendekatan Saintifik pada Pembelajaran Matematikadi MTs Negeri 3 Aceh Tengah
}

\author{
Bettri Yustinaningrum ${ }^{1}$, Nur Ainun Lubis ${ }^{2}$, Ega Gradini $^{3}$, Firmansyah $^{4}$, Aida Fitri $^{5}$ \\ 1,2,3,4 STAIN Gajah Putih Takengon, Aceh Tengah, ${ }^{5}$ MTs Negeri 3 Aceh Tengah \\ * bettri_yustinaningrum@yahoo.com
}

Diterima: Januari 2020. Disetujui: Mei 2020. Dipublikasikan: Juli 2020.

\begin{abstract}
ABSTRAK
Tujuan dari penelitian ini adalah untuk mendeskripsikan upaya integrasi nilai islam di MTsN 3 Aceh Tengah, mendeskripsikan perencanaan dan pelaksanaan program pembelajaran matematika MTs yang terintegrasi nilai Islam dengan pendekatan saintifik, dan mengetahui tingkat integrasi nilai Islam dengan pendekatan saintifik pada pelaksanaan pembelajaran matematika. Penelitian ini menggunakan pendekatan analitif, jenis penelitian adalah penelitian kualitatif. Pengambilan sampel menggunakan teknik purposive sampling. Tekhnik pengumpulan data menggunakan observasi, wawancara, dan dokumentasi. Teknik analisis data mengikuti konsep Miles dan Huberman. Pengujian kredibilitas dilakukan dengan triangulasi. Integrasi nilai-nilai Islam dalam pembelajarandiupayakan melalui program-program seperti menghafal ayat $\mathrm{Al}$ Qur'an, program one day one ayat. Perencanaan pembelajaran meliputi program tahunan, program semester, minggu efektif, kriteria ketuntasan minimal, silabus, dan RPP. Nilai islam yang dikembangkan adalah nilai hablun minAllah dan hablun minannafsi. MTsN 3 Aceh Tengah dalam pelaksanaan pembelajaran telah melakukan tahapan pendekatan saintifik seperti mengamati, menanya, mencoba, menalar, dan mengkomunikasikan. MTs Negeri 3 Aceh Tengah melakukan integrasi nilai islam dengan pendekatan saintifik pada tingkat strategi dan tingkat materi di tiap pertemuan masing-masing sebesar $100 \%$.
\end{abstract}

Kata kunci: integrasi, nilai Islam, pendekatan saintifik.

\begin{abstract}
The purpose of this study was to describe efforts to integrate Islamic values in MTsN 3 Aceh Tengah, describe the planning and implementation of MTs mathematics learning programs that integrated Islamic values with a scientific approach, and find out the level of integration of Islamic values with a scientific approach to the implementation of mathematics learning. This isa qualitative researchwith an analytic approach. The sample is obtained by a purposive sampling technique. Data collection techniques use observation, interviews, and documentation. Data analysis techniques follow the concept of Miles and Huberman. Credibility testing is done by triangulation. The integration of Islamic values in the learning is pursued through memorizing Al Qur'an verses and one day one verse programs. The learning planning includes annual programs, semester programs, effective weeks, minimum completeness criteria, syllabus, and lesson plans. The Islamic values developed are the values of hablun min Allah and hablun minannafsi. The implementation of learning has carried out the stages of a scientific approach such as observing, asking, trying, reasoning, and communicating. The integration of Islamic values with a scientific approach at the strategy level and material level at each meeting reach $100 \%$ each.

Keywords:integration, Islamic values, scientific approach.
\end{abstract}

How to Cite: Yustinaningrum, B., Lubis, N. A., Gradini, E., Firmansyah, \& Fitri, A. (2020). Integrasi Nilai Islami dengan Pendekatan Saintifik pada Pembelajaran Matematikadi MTs Negeri 3 Aceh Tengah. Journal of Medives: Journal of Mathematics Education IKIP Veteran Semarang, 4(2), 205-214. 


\section{PENDAHULUAN}

Globalisasi juga telah menimbulkan efek samping berupa pengikisan nilai-nilai luhur budaya bangsa, digantikan dengan budaya asing yang seringkali bertentangan dengan budaya yang dianut oleh peserta didik (Efendi, 2014). Pengikisan nilai budaya luhur ditandai dengan maraknya seks bebas, peredaran narkoba, tawuran, peredaran porno pada kalangan pelajar, dan sebagainya. Hasil survai sebuah lembaga survai yang mengambil sampel 33 provinsi di Indonesia pada tahun 2008. Remaja korban narkoba di Indonesia ada 1,1 juta orang. Berdasarkan data Pusat Pengendalian Gangguan Sosial DKI Jakarta, pelajar SD, SMP, SMA, yang terlibat tawuran mencapai $0,08 \%$ atau sekitar 1.318 siswa di DKI Jakarta (Kesuma, Dharma, \& Permana, 2011). Pengikisan nilai budaya luhur juga terjadi di kabupaten Aceh Tengah, pada tahun 2012 pelaku pelecehan seksual berusia di atas 15 tahun. Klasifikasi usia pelaku merujuk pada klasifikasi usia pelaku penyalahgunaan narkoba yang dikemukakan oleh Kepolisian Daerah Aceh yakni di bawah 15 tahun, 15-19 tahun, 20-24 tahun, 25-29 tahun, dan di atas 30 tahun (Bahri \& Fajriani, 2015).

Menurunya moralitas peserta didik merupakan dampak langsung dari pergeseran nilai yang memudarkan budaya dan norma masyarakat. Gejala pergeseran keyakinan nilai moral merupakan efek dari benturan nilai-nilai kultural dengan nilai yang lebih global. Karena itu, pergeseran dan benturan nilai merupakan tantangan pendidikan nilai dalam konteks pendidikan nasional
(Sauri, 2006). Undang-Undang No 20 Tahun 2003 tentang sistem pendidikan nasional pada pasal 3 menyebutkan bahwa pendidikan nasional berfungsi mengembangkan kemampuan dan membentuk watak serta peradaban bangsa yang bermartabat dalam rangka mencerdaskan kehidupan bangsa, bertujuan untuk berkembangnya potensi peserta didik agar menjadi manusia yang beriman dan bertakwa kepada Tuhan Yang Maha Esa, berakhlak mulia, sehat, berilmu, cakap, kreatif, mandiri, dan menjadi warga negara yang demokratis serta bertanggung jawab.

Dalam penyelenggaraan pendidikan diperlukan pegangan bersama untuk pelaksanaan pembelajaran. Pedoman tersebut lazim disebut kurikulum. Kurikulum yang diterapkan di Indonesia adalah kurikulum 2013. Kurikulum 2013 dalam pembelajaran matematika mene-kankan pentingnya keseimbangan kompetensi sikap, pengetahuan dan keterampilan, kemampuan matematika yang dituntut untuk dibentuk melalui pembelajaran berkelanjutan: dimulai dengan meningkatkan pengetahuan tentang metode-metode matematika, dilanjutkan dengan keterampilan menyajikan suatu permasalahan secara matematis dan menyelesaikannya, dan bermuara pada pembentukan sikap jujur, kritis, kreatif, teliti, dan taat aturan (Penyusun, 2013).

Berdasar dari beberapa aspek sebagaimana diterangkan di atas, maka karakteristik proses pembelajaran pada kurikukum 2013 disandarkan dengan pendekatan saintifik. Dalam pendekatan saintifik penilaian dilakukan berbasis 
kelas yang mengukur kognitif, afektif, dan psikomotorik (Majid, 2007). Penerapan penilaian tersebut diharapkan mampu meningkatkan pendidikan karakter peserta didik. Namun, menurut Tafsir, krisis dan penyimpangan moral berakar pada menurunya keimanan kepada Tuhan Yang Maha Esa, tetapi sistem pendidikan (dalam hal ini kurikulum) belum mengatasi hal tersebut, menurutnya seharusnya kuriku-lum menjadi pendidikan keimanan sebagai inti (core) sistem pendidikan nasional sehingga permasalahan keme-rosotan akhlak peserta didik bisa segera ditanggulangi (Tafsir, 2006).

Kurikulum yang diterapkan saat ini adalah kurikulum 2013 yang menekankan pada penguatan pendidikan karakter(Maulida, 2015). Pendidikan karakter menurut konsep PBKB dari Puskur ada 18 nilai. Hal ini berbeda dengan Nilai-nilai yang terkandung dalam al-Qur'an yang memiliki makna lebih luas, kompleks dan aplikatif jika dibandingkan dengan nilai-nilai yang muncul dari hasil pikiran manusia. Misalnya, makna ikhlas jauh lebih mendalam dibandingkan dengan makna rela berkorban.

Sehingga untuk mengatasi kelemahan kurikulum tersebut adalah dengan mengintegrasikan nilai Islam dalam materi pembelajaran. Salah satu materi pembelajaran yang dapat di integrasikan adalah matematika. Contoh dalam praktik pembelajaran matematika, guru mengajarkan matematika dengan strategi infusi (guru menekankan aspek nilai Al Quran yang ada dalam materi dalam mengajarkan matematika), analogi (guru melakukan analogi nilai kebaikan dalam mengajarkan matema-tika), narasi (dalam mengajarkan matematika guru menceritakan kisah-kisah matematika dan matematikawan muslim untuk diambil hikmahnya), dan Uswah Hasanah (dalam mengajarkan matematika guru menunjukkan perilaku yang patut dicontoh terkait matematika, misalnya kejujuran, kesungguhan, ketepatan, ketaatan, dan ketelitian) (Mutijah, Model Integrasi Matematika dengan Nilai-Nilai Islam dan Kearifan Lokal Budaya dalam Pembelajaran Matematika, 2018).

Nilai islam yang merupakan nilai yang bersumber langsung dari Al Qur'an dan Hadits memiliki arti penting dalam pendidikan terutama umat islam. Menurut M. Quraish Shihab nilai-nilai Islam yang ada dalam Al Quran adalah nilai akidah, nilai syariah, nilai akhlak meliputi: 1) akhlak terhadap Allah, 2) akhlak terhadap sesama manusia, 3) akhlak terhadap tumbuhan, hewan, dan lain-lainnya (lingkungan) (Shihab, 2013). Nilai islam yang diintegrasikan dalam pembelajaran mampu mengantarkan siswa pada ketercapaian pengetahuan (domain kognitif) serta ketercapaian pemahaman dan penerapan nilai-nilai islam. Integrasi nilai islam dalam pembelajaran dibedakan beberapa tingkatan antara lain tingkat filosofi,dan materi, metodologi dan strategi (Abdullah, 2004). Melalui pembelajaran terintegrasi diharapkan esensi dari pembelajaran yaitu pengembangan pribadi peserta didik dapat dicapai secara berkelanjutan. 
Memperhatikan alasan tersebut, peneliti tertarik untuk melakukan penelitian lebih lanjut dalam upaya menggali informasi yang lebih dalam dan komprehensif di lapangan yang bersifat empiris seputar persiapan dan pelaksanaan aktifitas pembelajaran madrasah di Aceh Tengah terutama mata pelajaran matematika. Semua proses penelitian tersebut berfokus pada upaya integrasi nilai islam dengan pendekatan saintifik di madrasah, deskripsi pe-rencanaan dan pelaksanaan nilai islam yang dintegrasikan pembelajaran serta tingkat integrasi pada mata pelajaran matematika.

\section{METODE PENELITIAN}

Jenis Penelitian dalam penelitian ini adalah penelitian kualitatif-kuantitatif. Pendekatan penelitian yang digunakan adalah pendekatan deskriptif analitif untuk mendeskripsikan upaya integrasi dan proses perencanaan serta pelaksana-an pendekatan saintifik di MTs. Teknik sampling untuk pengambilan sumber data primer menggunakan purposive sampling dari 21 MTs di Aceh Tengah diambil satuMTs yaitu MTsN 3 Aceh Tengah. Pengambilan sample ini dilakukan karena MTsN 3 Aceh Tengah salah satu MTs yang melaksanakan program integrasi nilai islam dengan pendekatan saintifik. Pengumpulan data melalui observasi, wawancara semi-struktur, dan dokumentasi. Instrumen penelitian adalah peneliti itu sendiri. Teknik analisis data dalam penelitian ini adalah analisis data kualitatif, mengikuti konsep yang diberikan Miles dan Huberman(Miles \& Hubberman, 1994). Dalam penelitian ini pengujian kredibili-tas dilakukan dengan cara triangulasi.

\section{HASIL DAN PEMBAHASAN}

Upaya Integrasi Nilai-Nilai Islam di Mts Negeri 3 Aceh Tengah

Untuk mengetahui upaya-upaya yang dilakukan sekolah dalam mengintegrasikan nilai-nilai Islam dapat dilihat pada cuplikan 1a sampai dengan 1c berikut.

\section{Cuplikan 1a}

Peneliti: "Program-program MTs apa saja yang mendukung ketercapaian lingkungan dan akademis yang penuh nilai islam?"

Waka Kurikulum: "Kami selain dari jam pembelajaran di pagi hari itu setiap pagi itu ada kegiatan khusus selain jam pembelajaran umumnya jam 8 pembelajaran sejak pagi itu kalau hari senin kami upacara, kalau selasa kami one day one ayat 30 menit".

Peneliti: "MasyaAllah."

Waka Kurikulum: "Setiap kelas dipandu wali kelasnya melaksanakan kegiatan tersebut. Surat-surat pendek di jadwal dari surat ini sampai surat ini. Kelas 2 dari surat ini sampai surat ini, kalau lebih alhamdulilah. Kadang-kadang siswa diluar ada ngaji kalau program ini sudah sangat mudah, kalau gak bisa ngaji kami bimbing di sini, pagi-pagi tercatat terjadwal jadi setiap naik kelas sudah sesuai".

Cuplikan $1 b$

Peneliti: "Apa keunggulan sekolah ini dibanding sekolah lain?"

Guru Matematika: "Lebih benar dengan one day one ayat kita bisa menghafal surat kalau di rumah kita kan malam-malam”.

Cuplikan 1c

Peneliti: "Perubahan apa yang kamu rasakan setelah sekolah di sini?" 
Siswa: 'Sebelumnya malas hafal al-qur'an sekarang karena ada one day one ayat jadi lebih termotivasi bisa menghafal lebih banyak".

Berdasarkan wawancara peneliti dengan Waka Kurikulum, Guru Matematika, dan siswa diperoleh bahwa MTs Negeri 3 Aceh Tengah ingin menerjemahkan visi dan misi madrasah secara baik kepada seluruh komponen yang ada di madrasah. Visi madrasah adalah "mewujudkan siswa yang berkarakter dan berkepribadian, disiplin, terampil, berprestasi dan berakhlakul karimah berlandaskan moral dan spiritual". Dengan salah satu misi madrasah adalah "meningkatkan kualitas guru dan mewujudkan proses pembelajaran yang islami”. Untuk mewujudkan visi dan misi tersebut dibuat program-program penanaman nilai-nilai islam yang salah satunya yaitu melalui kegiatan one day one ayat 30 menit. Kegiatan one day one ayat dilaksanakan setiap hari selasa sebelum pembelajaran jam pertama selama 30 menit. Tujuan kegiatan one day one ayat yaitu untuk meningkatkan bacaan dan hafalan Al-Quran siswasiswi MTs Negeri 3 Takengon.

Persiapan dan Perencanaan Guru Mts Negeri 3 Aceh Tengah dalam Membuat Program Pembelajaran Matematika yang Terintegrasi Nilai Islam dengan Pendekatan Saintifik

\section{Perencanaan Pembelajaran}

Kurikulum yang dipakai di MTs Negeri 3 Aceh Tengah adalah kurikulum 2013, berdasarkan hasil wawancara dan observasi diperoleh data bahwa perenca-naan pembelajarannya dilakukan dengan menyiapkan perangkat pembelajaran meliputi program tahunan, program semester, minggu efektif, kriteria ketuntasan minimal, silabus, dan RPP. Nilai-nilai islam yang dikembangkan dalam kegiatan perencanaan pembelajar-an dengan materi persamaan kuadrat berdasarkan hasil observasi pembelajaran dan perangkat antara lain: 1) nilai yang terkait dengan hablun minallah (hubungan seorang hamba kepada Allah), seperti ketaatan, syukur, serta 2) nilai yang berhubungan dengan hablun minannafsi (diri sendiri), seperti kejujuran, disiplin.

\section{Pelaksanaan Pembelajaran}

Pelaksanaan pembelajaran dimulai dengan kegiatan awal berupa pemberian salam, pembacaaan ayat $\mathrm{Al}$ Qur'an, memberikan apersepsi terkait dengan ibadah seperti shalat, memberi contoh nilai kejujuran dalam kehidupan sehari-hari.

Dari hasil observasi pelaksanaan pada Tabel 1, pembelajaran pada pertemuan 1 sampai 9 materi persamaan kuadrat di MTs Negeri 3 Aceh Tengah berdasarkan pendekatan saintifik dibagi kedalam 5 tahapan.

\section{Mengamati}

Dari hasil observasi pelaksanaan pembelajaran pada pertemuan 1 sampai 9 diperoleh data bahwa tahapan mengamati seperti guru menyajikan kegiatan ketrampilan mengamati, siswa mengum-pulkan data tentang materi yang diberikan guru, siswa mengamati materi yang diberikan guru telah dilakukan dalam pelaksanaan 
Tabel 1. Observasi Pelaksanaan Pembelajaran

\begin{tabular}{|c|c|c|c|}
\hline \multirow{2}{*}{ No. } & \multirow{2}{*}{ Indikator/Aspek Yang Diamati } & \multicolumn{2}{|c|}{ Realisasi } \\
\hline & & $\mathrm{Ya}$ & Tidak \\
\hline & Mengamati & & \\
\hline 1 & Guru menyajikan kegiatan ketrampilan mengamati & $\sqrt{ }$ & \\
\hline 2 & Siswa mengumpulkan data tentang materi yang sudah diberikan guru & $\sqrt{ }$ & \\
\hline 3 & $\begin{array}{l}\text { Siswa mengamati materi yang sudah diberikan oleh guru } \\
\text { Menanva }\end{array}$ & $\sqrt{ }$ & \\
\hline 4 & Guru memancing peserta didik bertanya & $\sqrt{ }$ & \\
\hline 5 & Siswa mengajukan pertanyaan yang terkait materi & $\sqrt{ }$ & \\
\hline 6 & $\begin{array}{l}\text { Guru memberikan penjelasan dengan contoh-contoh yang sarat dengan } \\
\text { nilai-nilai keislaman } \\
\text { Mencoba }\end{array}$ & $\sqrt{ }$ & \\
\hline 7 & Guru menyajikan kegiatan untuk ketrampilan mencoba & $\sqrt{ }$ & \\
\hline 8 & $\begin{array}{l}\text { Siswa merancang percobaan untuk menguji hipotesis } \\
\text { Menalar }\end{array}$ & $\sqrt{ }$ & \\
\hline 9 & Guru meyajikan kegiatan menalar & $\sqrt{ }$ & \\
\hline 10 & $\begin{array}{l}\text { Siswa menalar materi berdasarkan hasil observasi dan percobaan serta } \\
\text { mengaitkan materi yang diajarkan dengan mengambil dalil dari al- } \\
\text { Qur'an atau al-Hadits } \\
\text { Mengkomunikasikan }\end{array}$ & $\sqrt{ }$ & \\
\hline 11 & Guru menyajikan kegiatan untuk ketrampilan mengkomunikasikan & $\sqrt{ }$ & \\
\hline 12 & $\begin{array}{l}\text { Siswa mengkomunikasikan informasi yang ditemukan baik melalui } \\
\text { tulisan atau disampaikan secara lisan di depan kelas }\end{array}$ & $\sqrt{ }$ & \\
\hline 13 & $\begin{array}{l}\text { Guru memperinci nilai-nilai Islam yang muncul dalam materi } \\
\text { pembelajaran dan berusaha menanamkannya dalam benak dan perilaku } \\
\text { siswa }\end{array}$ & $\sqrt{ }$ & \\
\hline
\end{tabular}

pembelajaran. Pada tahapan mengamati guru memberikan permasalahan seperti tabel kuadrat sempurna untuk dilengkapi siswa.

\section{Menanya}

Dari hasil observasi pelaksanaan pembelajaran pada pertemuan 1 sampai 9 diperoleh data bahwa tahapan menanya seperti guru memancing peserta didik bertanya, siswa mengajukan pertanyaan terkait materi, guru memberikan penjelasan dengan contoh-contoh yang sarat dengan nilainilai keislaman telah dilakukan dalam pelaksanaan pembela-jaran. Pada tahapan menanya guru memberikan contoh-contoh nilai-nilai keislaman seperti nilai kejujuran, nilai ketaatan ibadah.

\section{Mencoba}

Dari hasil observasi pelaksanaan pembelajaran pada pertemuan 1 sampai 9 diperoleh data bahwa tahapan mencoba seperti guru menyajikan kegiatan untuk ketrampilan mencoba, siswa merancang percobaan untuk menguji hipotesis telah dilakukan dalam pelaksanaan pembela-jaran. Pada tahapan mencoba siswa merancang percobaan untuk menguji hipotesis dengan jalan mengajukan berbagai jawaban terkait masalah yang diberikan guru.

\section{Menalar}

Dari hasil observasi pelaksanaan pembelajaran pada pertemuan 1 sampai 9 diperoleh data bahwa tahapan menalar 
seperti guru menyajikan kegiatan menalar, siswa menalar materi berdasarkan hasil observasi dan percobaan serta mengaitkan materi dengan nuansa islami telah dilakukan dalam pelaksanaan pembelajaran. Pada tahapan menalar materi persamaan kuadrat, siswa menalar materi dengan mengaitkan nuansa islami dengan memberikan contoh bahwa dalam rakaat shalat tidak boleh tertukar, konsep ini juga dipakai dalam menjelaskan koefisien yang terdapat pada pangkat persamaan kuadrat. Koefisien pangkat dua tidak bisa ditukar dengan koefisien pangkat satu semua sesuai aturan masing-masing.

\section{Mengkomunikasikan}

Dari hasil observasi pelaksanaan pembelajaran pada pertemuan 1 sampai 9 diperoleh data bahwa tahapan mengkomunikasikan seperti guru menyajikan kegiatan untuk ketrampilan mengkomunikasikan, siswa mengkomunikasikan informasi yang ditemukan, guru memperinci nilai-nilai islam yang muncul dalam materi pembelajaran telah dilakukan dalam pelaksanaan pembela-jaran. Pada kegiatan mengkomunikasi-kan guru telah memperinci nilai-nilai islam yang akan ditanamkan dalam benak siswa seperti nilai ketaatan ibadah, sikap jujur, sikap disiplin, dan sikap sopan dalam mengajukan pendapat.

\section{Tingkat Integrasi Nilai Islam dengan Pendekatan Saintifik pada Pelaksanaan Pembelajaran Matematika MTs Negeri 3 Aceh Tengah}

Strategi pelaksanaan pembelajaran matematika MTs Negeri 3 Aceh Tengah yang terintegrasi nilai Islam dengan pendekatan saintifik yaitu melalui keterampilan guru mengajar. Pengin-tegrasian nilai-nilai ajaran Islam dalam pembelajaran matematika MTs Negeri 3 Aceh Tengah berdasarkan pada pengembangan kurikulum UIN Sunan Kalijaga (Abdullah, 2004) tergolong pada pengintegrasian tingkat strategi. Yang dimaksudtingkat strategi di sini adalah pelaksanaan atau praksis dari proses pembelajaran matematika. Dalam konteks ini, setidaknya kualitas keilmuan serta ketrampilan mengajar guru menjadi kunci keberhasilanpembelajaran berbasis pola pikir terintegrasi. Penanaman nilai islam dalam pembelajaran matematika misalnya pada saat apersepsi guru memberikan motivasi yang terkait kehidupan sehari-hari. Contoh materi perbandingan, pada saat apersepsi guru menjelaskan perbedaan pahala shalat subuh yang dikerjakan di rumah dibandingkan dengan masjid berbeda. Integrasi nilai islam dengan pendekatan saintifik pada melalui pemberian contoh ibadah dapat menumbuhkan akhlak yang baik. Hal ini didukung pendapat Djamal yang menyatakan bahwa ibadah merupakan kewajiban seluruh umat Islam sebagai cerminan nilai-nilai ajaran Islam yang ada pada dirinya. Semakin besar nilai-nilai ajaran Islam yang diterapkan pada dirinya, tentu semakin baik pengamalan ibadahnya dalam kehidupan sehari-hari, dan semakin baik pengamalan ibadah seseorang maka hal tersebut dapat menumbuhkan akhlak yang baik 
(Djamal, 2017). Model integrasi ini diartikan bahwa matematika digunakan untuk melaksanakan perintah-perintah Allah yang termuat dalam Al Quran, dan dalam praktik pembelajarannya matematika diajarkan dalam rangka mengembangkan potensi intelektual dan spiritual (Mutijah, Model Integrasi Matematika dengan Nilai-nilai Islam dan Kearifan Lokal Budaya Dalam Pembelajaran Matematika, 2018).

Selain tingkat strategi, pengintegrasian juga dilakukan pada tingkat materi. Pengintegrasian nilai ajaran islam dengan pembelajaran matematika tingkat materi yaitu Integrasi dan interkoneksi pada level materi merupakan suatu proses mengintegrasikan nilai-nilai kebenaran universal umumnya dan keislaman khususnya ke dalam pengajaran umum. Contohnya pada materi kelipatan bilangan terdapat pengaitan dengan nuansa islami, pahala itu berlipat-lipat ganda kalau mengerjakan sedekah maka akan dilipat gandakan pahalanya.

Dari hasil lembar observasi aktivitas pembelajaran selama 9 kali pertemuan di kelas diperoleh data yang dapat dilihat pada Tabel 2.

Tabel 2. Frekuensi Tingkat Integrasi Nilai Islam dengan Pendekatan Saintifik

\begin{tabular}{clc}
\hline No. & $\begin{array}{c}\text { Tingkat Integrasi } \\
\text { Nilai Islam } \\
\text { dengan } \\
\text { Pendekatan } \\
\text { Saintifik }\end{array}$ & $\begin{array}{c}\text { Frekuensi } \\
\text { Penerapan } \\
\text { Integrasi Nilai } \\
\text { Islam dengan } \\
\text { Pendekatan } \\
\text { Saintifik }\end{array}$ \\
\hline $\mathbf{1}$ & Tingkat Filosofi & 0 \\
$\mathbf{2}$ & Tingkat Materi & 9 kali \\
$\mathbf{3}$ & Tingkat & 0 \\
$\mathbf{4}$ & Metodologi & 9 kali \\
\hline
\end{tabular}

Dari Tabel 2 diketahui bahwa penerapan integrasi nilai islam dengan pendekatan saintifik pada tingkat filosofis dan metodologi di MTs Negeri 3 Aceh Tengah sebanyak 0 kali $(0 \%)$. Sedangkan pada tingkat materi sebanyak 9 kali dari 9 kali pertemuan $(100 \%)$ dan pada tingkat strategi sebanyak 9 kali dari 9 kali pertemuan (100\%). Dari data di atas disimpulkan bahwa MTs Negeri 3 Aceh Tengah melakukan integrasi nilai islam dengan pendekatan saintifik pada tingkat strategidan tingkat materi pada tiap pertemuan. Hal ini berarti bahwa integrasi yang dilaksanakan baru terbatas pada tingkat materi dan strategi sedangkan untuk filosofi dan metodologi belum dilaksanakan.Guru matematika mengalami kesulitan pada saat mengintegrasikan nilai islam dengan matematika pada tingkat filosofi dan metodologi.

\section{KESIMPULAN DAN SARAN}

Berdasarkan hasil temuan dan data yang didapatkan dari hasil wawancara dan observasi, kemudian dibahas dalam pembahasan diperoleh beberapa kesim-pulan sebagai berikut.

1. Integrasi nilai-nilai Islam dalam pembelajaran MTs Negeri 3 Aceh Tengah diupayakan melalui program-program seperti menghafal ayat Al Qur'an, program one day one ayat.

2. Perencanaan pembelajaran MTs Negeri 3 Aceh Tengah dilakukan dengan menyiapkan perangkat pembelajaran meliputi program tahunan, program semester, minggu efektif, kriteria ketuntasan minimal, 
silabus, dan RPP. Nilai islam yang dikembangkan di MTs Negeri 3 Aceh Tengah adalah nilai hablun minallah dan hablun minannafsi.Nilai Islam dikembangkan berdasarkan ketrampilan guru dalam pembelajaran dan penguasaan pengetahuan guru dalam mengaitkan nilai islam dengan materi matematika MTs Negeri 3 Aceh Tengah dalam pelaksanaan pembelajaran telah melakukan tahapan pendekatan saintifik seperti mengamati, menanya, mencoba, menalar, dan mengkomunikasikan.

3. MTs Negeri 3 Aceh Tengah melakukan integrasi nilai islam dengan pendekatan saintifik pada tingkat strategi dan tingkat materi pada tiap pertemuan yang masingmasing sebesar $100 \%$.

Setelah melakukan penelitian dan terlibat langsung maka penulis menyumbangkan sedikit saran antara lain sebagai berikut.

1. Dalam proses pembelajaran di kelas, hendaknya guru selalu mencari nilainilai Islam yang muncul dalam perangkat dan pelaksanaan pembelajaran dengan memberikan penjelasan yang kongkrit dan dialami oleh siswa, sehingga pembelajaran akan berlang-sung lebih bermakna, kontekstual, dan sarat dengan nilainilai yang berkembang dalam kehidupan siswa.

2. Integrasi nilai-nilai ajaran Islam dalam pembelajaran matematika bukan hanya kebutuhan tetapi sudah merupakan keharusan dan tanggung jawab terutama bagi lembaga pendidikan Islam. Oleh karena itu bagi MTs Negeri 3 Aceh Tengah disarankan untuk tetap melanjutkan pembelajaran terintegrasi yang telah diterapkan dengan cara meningkatkan kualitas komponenkomponennya.

\section{DAFTAR PUSTAKA}

Abdullah, A. (2004). Kerangka Dasar Keilmuwan dan Pengembangan Kurikulum UIN Sunan Kaliaga Yogyakarta. Yogyakarta: Pokja Akademik.

Bahri, S., \& Fajriani. (2015). Suatu Kajian Awal Terhadap Tingkat Pelecahan Seksual di Aceh. Majelis Pendidikan Daerah Aceh, 50-65.

Djamal, S. M. (2017). Penerapan Nilainilai Ajaran Islam dalam Kehidupan Masyarakat di Desa Garuntungan Kecamatan Kindang Kabupaten Bulukumba. Adabiyah, 161-179.

Efendi, A. (2014). Implementasi Kearifan Budaya lokal Pada Masyarakat Adat Kampung Kuta Sebagai Sumber Pembelajaran IPS. Sosio Didaktika, 211-218.

Kesuma, Dharma, \& Permana, J. (2011). Pendidikan Karakter Kajian Teori dan Praktek. Bandung: Remaja Rosda Karya.

Majid, A. (2007). Perencanaan Pembelajaran (Mengembangkan Standar Kompetensi Guru). Bandung: Remaja Rosda Karya.

Maulida. (2015). Pengembangan Bahan Ajar Berbasis Pendidikan Karakter dalam Mendukung Implementasi Kurikulum 2013. Berkala Ilmiah Pendidikan Fisika, 17. 
214 | Bettri Y., Nur Ainun L., Ega G., Firmansyah, Aida F. - Integrasi Nilai Islami dengan Pendekatan Saintifik pada ....

Miles, B. M., \& Hubberman, A. M. (1994). Qualitative Data Analysis. London : International Educational and Profesional Publisher.

Mutijah. (2018). Model Integrasi Matematika dengan Nilai-nilai Islam dan Kearifan Lokal Budaya Dalam Pembelajaran Matematika. Jurnal Pendidikan Matematika, 51-75.
Penyusun.(2013).Buku Guru Matematika Kelas X. Jakarta: Kemendikbud.

Sauri, S. (2006). Membangun Komunikasi dalam Keluarga. Bandung : PT Genesindo.

Tafsir, A. (2006). Filsafat Pendidikan Islam. Bandung: Rosda Karya. 